University of Nebraska - Lincoln

DigitalCommons@University of Nebraska - Lincoln

\title{
Effect of Deficit Irrigation and Fertilization on Cucumber
}

Kamal H. Amer

Minofia University

Sally A. Midan

Minofia University

Jerry L. Hatfield

USDA-ARS, jerry.hatfield@ars.usda.gov

Follow this and additional works at: https://digitalcommons.unl.edu/usdaarsfacpub

Amer, Kamal H.; Midan, Sally A.; and Hatfield, Jerry L., "Effect of Deficit Irrigation and Fertilization on Cucumber" (2009). Publications from USDA-ARS / UNL Faculty. 1349.

https://digitalcommons.unl.edu/usdaarsfacpub/1349

This Article is brought to you for free and open access by the U.S. Department of Agriculture: Agricultural Research Service, Lincoln, Nebraska at DigitalCommons@University of Nebraska - Lincoln. It has been accepted for inclusion in Publications from USDA-ARS / UNL Faculty by an authorized administrator of DigitalCommons@University of Nebraska - Lincoln. 


\title{
Effect of Deficit Irrigation and Fertilization on Cucumber
}

\author{
Kamal H. Amer, Sally A. Midan, and Jerry L. Hatfield*
}

\begin{abstract}
Soil water budgets are essential in determining the proper timing and amount of irrigation. Organic fertilizers can be substituted for commercial fertilizers; however, information is sparse on the interaction of irrigation management and nutrient source on cucumber (Cucumis sativus L.) production. This study evaluated nutrient source and irrigation management on growth and yield of cucumber grown in the arid area of Egypt. A field experiment was conducted using cucumber grown in northern Egypt at Shibin El-Kom in 2006 and 2007 to evaluate water use and fertilizer rate and type. Three irrigation deficits and seven fertilization types were arranged in a randomized split-plot design with irrigation rates as main plots and fertilizer treatments within irrigation rates. Irrigation treatments were a ratio of crop evapotranspiration (ET) as: 1.0 ET, 0.84 ET, and 0.64 ET. Fertilizer treatments were applied at the recommended rate of $\mathrm{N}$ either as a commercial fertilizer or with organic manure. Chlorophyll $a$ and $b$, leaf area index, and yield were greatest with the lowest ratios of male to female flowers when adequate water and high $\mathrm{N}$ were used (1.0 ET with chicken manure at $7 \mathrm{Mg} / \mathrm{ha}$ ). Seasonal water use was 498 and $471 \mathrm{~mm}$ for $1.0 \mathrm{ET}$ in 2006 and 2007 plantings over the $125 \mathrm{~d}$ growing season, respectively. The yield reduction coefficient averaged 0.77 . An optimal scheduling was statistically developed based on crop response in deficit irrigation to achieve maximum yield for different uniformity coefficient variation values. Cucumber performance was significantly affected by both irrigation and nutrient deficiencies.
\end{abstract}

$\mathrm{W}$ ATER is an essential factor in agriculture production in Egypt. In arid regions where irrigation is required for crop production, growers are seeking methods to save water by increasing irrigation efficiency. Optimum irrigation scheduling based on water use patterns and crop response to water deficit can potentially improve water use efficiency. Trickle irrigation applies less water than sprinkler and surface systems since only a portion of the soil surface area is irrigated. Nutrients are essential to plant growth and maximum plant growth is achieved when the nutrient availability coincides with water availability. Mineral fertilizers are readily available after application, and application can be timed to meet crop needs throughout the growing season. Nutrient release from organic fertilizers is temperature dependent and relatively slow during the season. Consequently, the nutrient release from organic fertilizers may not coincide with crop needs. If the nutrient released is mobile, like nitrate, and is not used by the crop, it can be leached from the root zone, thereby posing a potential environmental hazard. If organic fertilizers include a manure

K.H. Amer and S.A. Midan, Minofia Univ., Egypt; and J.L. Hatfield, USDA-ARS National Laboratory for Agriculture and the Environment, 2110 University Blvd., Ames, IA 50011. Mention of a specific trade name, product, or manufacturer does not imply endorsement or preferential treatment by Minofia University or USDA-ARS. Received 18 Mar. 2009. *Corresponding author (jerry.hatfield@ars.usda.gov).

Published in Agron. J. 101:1556-1564 (2009)

Published online 7 Oct. 2009

doi:10.2134/agronj2009.0112

Copyright (C) 2009 by the American Society of Agronomy, 677 South Segoe Road, Madison, WI 53711. All rights reserved. No part of this periodical may be reproduced or transmitted in any form or by any means, electronic or mechanical, including photocopying, recording, or any information storage and retrieval system, without permission in writing from the publisher.

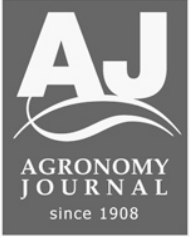

component, unsafe vegetable products can result when the vegetable has physical contact with manure.

Cucumber is one of the most popular vegetables cultivated in our world. It requires more water than grain crops $(\mathrm{Li}$ and Wang, 2000; Mao et al., 2003). Mao et al. (2003) found that fresh fruit yields of cucumber were highly affected by the total volume of irrigation water at all growth stages. The least productive irrigation regimes were those that had water deficiencies during fruiting stages (Mao et al., 2003). Variation in soil moisture in the root zone from beginning to end of growing season will be small under trickle irrigation due to the small volume of wetted soil. Consequently, irrigation water applied plus rainfall (W) which achieves the corresponding yield $(\mathrm{Y})$ can be mostly considered as plant evapotranspiration (ET) until deep drainage occurs as in surplus irrigation application. Optimum application water $\left(\mathrm{W}_{\mathrm{m}}\right)$ estimated to equal standard evapotranspiration $\left(\mathrm{ET}_{\mathrm{m}}\right)$ achieves the maximum yield.

Mao et al. (2003) working on cucumber found a linear relationship for whole growth period in greenhouses as: $\mathrm{Y}=$ $0.095 \mathrm{~W}+119.6$ with $r^{2}=0.885$ where $\mathrm{Y}$ is in $\mathrm{Mg} / \mathrm{ha}$ and $\mathrm{W}$ is in $\mathrm{mm}$. The cucumber maximum yield was $194 \mathrm{Mg} / \mathrm{ha}$ for $726.2 \mathrm{~mm}$ optimum water use. The yield reduction coefficient $\left(K_{\mathrm{y}}\right)$ was determined as 0.409 by applying deficit irrigation treatments. Simseka et al. (2005), also working in cucumber, found that fruit yield ranged from 40 to $70 \mathrm{Mg} / \mathrm{ha}$ and was significantly reduced as drip irrigation rate decreased from 900 to $600 \mathrm{~mm}$. They found the following polynomial relationships from their study:

$$
\mathrm{Y}=-0.00014 \mathrm{~W}^{2}+0.268 \mathrm{~W}-55.086, r^{2}=0.91
$$

Abbreviations: DI, drip irrigation; ET, evapotranspiration; LAI, leaf area index; SDI, subsurface drip irrigation. 


$$
\mathrm{Y}=0.00032 \mathrm{ET}^{2}+0.5952 \mathrm{ET}-201.55, r^{2}=0.93
$$

The relations were linearly correlated as $\mathrm{Y}_{\mathrm{m}}=70 \mathrm{Mg} / \mathrm{ha}$ and $\mathrm{W}_{\mathrm{m}}=\mathrm{ET}_{\mathrm{m}}=900 \mathrm{~mm}$ and rewritten for this study as follows:

$$
\begin{aligned}
& \mathrm{Y}=0.051 \mathrm{~W}+27.98, r^{2}=0.885 \\
& \mathrm{Y}=0.099 \mathrm{ET}-11.68, r^{2}=0.88
\end{aligned}
$$

Yuan et al. (2006) studied cucumber production functions related to irrigation water applied (W) using drip irrigation under rain shelter for spring and autumn cucumber fruit yield (Y) are: spring cucumber fruit yield: $\mathrm{Y}=10.147 \mathrm{~W}-86.207$ with $r^{2}=0.99$ when $\mathrm{W}$ ranged from 150 to $320 \mathrm{~mm}$, and autumn cucumber fruit yield: $\mathrm{Y}=4.46 \mathrm{~W}+730.342$ with $r^{2}=$ 0.74 when $\mathrm{W}$ ranged from 200 to $420 \mathrm{~mm}$.

In comparing cucumber to other vegetables, Sammis and Wu (1986) found that tomato (Lycopersicon esculentum Mill.) fruit yield increased linearly with increasing application up to $467 \mathrm{~mm}$ where maximum yield was $99 \mathrm{Mg} / \mathrm{ha}$. When water applied was reduced to $280 \mathrm{~mm}$, the yield decreased to 60.15 $\mathrm{Mg} / \mathrm{ha}$. Therefore, the yield reduction coefficient was recorded as 0.98 . They found water irrigation greater than $467 \mathrm{~mm}$ resulted in no significant increase in yield.

Expressing yield and application of water or ET in relative terms by dividing yield $(\mathrm{Y})$ by maximum yield $\left(\mathrm{Y}_{\mathrm{m}}\right)$ and ET by $\mathrm{ET}_{\mathrm{m}}$ and subtracting from one results in a relative deficit water production function:

$$
1-\frac{\mathrm{Y}}{\mathrm{Y}_{\mathrm{m}}}=0.98\left(1-\frac{\mathrm{ET}}{\mathrm{ET}_{\mathrm{m}}}\right)
$$

The coefficient of 0.98 is a crop deficit coefficient and relates the relative reduction in yield to the relative reduction in ET.

Hanson et al. (2003) working on garlic (Allium sativum L.) found that yield significantly responded to water that was applied between 100 and $350 \mathrm{~mm}$ in a linear relationship under sprinkler irrigation and insignificantly responded to $\mathrm{N}$ applications in a range of 112 to $449 \mathrm{~kg} / \mathrm{ha}$. The linear relation was found in the 2000 growing season as: $\mathrm{Y}=0.03 \mathrm{~W}+10$ with $r^{2}=0.91$. Enciso et al. (2007) working on onion 'Cougar' (hybrid, yellow short day sweet onion; Allium cepa L.) during the 2006-2007 fall-spring growing season with subsurface drip irrigation found that onion yield was 36.4, 39.2, and 42.5 $\mathrm{Mg} / \mathrm{ha}$ for 313, 353, and $393 \mathrm{~mm}$ water use (water applied plus $133 \mathrm{~mm}$ rainfall) using an ET-based irrigation scheduling approach, respectively. Yield was 43.6, 42.2, and $34.4 \mathrm{Mg} / \mathrm{ha}$ for 413,363 , and $323 \mathrm{~mm}$ water use using a direct soil moisture monitoring based approach. The data were correlated in this study as follows:

$$
\begin{aligned}
& \mathrm{Y}=0.087 \mathrm{~W}+8.142 \text { with } r^{2}=0.85 \\
& 1-\frac{\mathrm{Y}}{\mathrm{Y}_{\mathrm{m}}}=0.733\left(1-\frac{\mathrm{W}}{\mathrm{W}_{\mathrm{m}}}\right) \text { with } r^{2}=0.83
\end{aligned}
$$

Ahmet et al. (2004) using furrow irrigation on summer squash (Cucurbita pepo L.) also found that fruit yield was significantly increased in a linear relationship by increasing both irrigation water and water consumptive use in a range of 250 to $530 \mathrm{~mm}$ with deficit irrigation where no deep seepage has occurred as follows:

$$
\begin{aligned}
& \mathrm{Y}=0.076 \mathrm{I}+3.835 \text { with } r^{2}=0.79 \\
& \mathrm{Y}=0.0939 \mathrm{ET}-7.9448 \text { with } r^{2}=0.92
\end{aligned}
$$

Al-Omran et al. (2005) studied squash (Cucurbita pepo L.) using both DI and SDI in sandy soils with three clay deposits also found that fruit yield was a linear relationship to increasing irrigation water level for each season within the same treatment. They found that fruit yields significantly increased with clay deposits compared with control. The differences between SDI and DI on fruit yields were also significant.

The purpose of the study was to evaluate irrigation scheduling based on deficit irrigation levels and to evaluate cucumber performance under varying irrigation regimes and combinations of $\mathrm{N}$ from either commercial or manure sources. One goal of the study was to evaluate combinations of organic and chemical fertilizers on cucumber yield and performance.

\section{MATERIALS AND METHODS}

Beta-alfa cucumber was grown for two seasons in loamy clay soil located at an arid site in northern Egypt (Shibin El-Kom area, $17.9 \mathrm{~m}$ above sea level, $30^{\circ} 32^{\prime} \mathrm{N}, 31^{\circ} 03^{\prime} \mathrm{E}$ ). The crop was planted on 1 March in a nursery, transplanted to the field on 13 April, and terminated on 15 August in both the 2006 and 2007 seasons as planned. A randomized split-plot design with irrigation treatments as main plots and nutrient source as random treatments within an irrigation treatment and three replicates of each treatment was established for the 2006 and 2007 seasons (Fig. 1). The same design was used in the 2007 season in a new site near the 2006 site. Block size was 18 by $21 \mathrm{~m}$ with $1-\mathrm{m}$ row width and a $0.3-\mathrm{m}$ spacing between plants within rows as shown in Fig. 1. Plants were adequately watered in first and second irrigations and irrigation treatments were initiated at the third irrigation. Irrigation water with $0.86 \mathrm{dS} / \mathrm{m}$ was applied using a trickle system when soil water was reduced to between 50 and $60 \%$ of available water in the upper $1 \mathrm{~m}$ of the soil profile. Water was uniformly distributed by using good quality drippers, drippers grouping, and individually irrigating the treatments. By using this arrangement, lateral length was short enough to ensure uniform distribution within a row. Water applied was equivalent to 100,80 , and $60 \%$ based on crop evapotranspiration (1.0 ET) determined from soil water contents before and after irrigation. Irrigation treatments were rated as 1.0 ET, 0.84 ET, and 0.64 ET from seasonal water use.

Fertilization treatments imposed for this study were: T1 (160 kg/ha N), T2 $(80 \mathrm{~kg} / \mathrm{ha} \mathrm{N}$ with $17 \mathrm{Mg} / \mathrm{ha} \mathrm{farm-}$ yard manure), T3 (160 kg/ha N with $17 \mathrm{Mg} / \mathrm{ha}$ farmyard manure), T4 (80 kg/ha $\mathrm{N}$ with $7 \mathrm{Mg} /$ ha rabbit manure), T5 (160 kg/ha N with $7 \mathrm{Mg} / \mathrm{ha}$ rabbit manure), T6 (80 kg/ha N with $7 \mathrm{Mg} /$ ha chicken manure), and T7 (160 kg/ha N with 7 $\mathrm{Mg} /$ ha chicken manure) in 2006 and 2007 summer seasons. Chemical analysis of the manure sources are given in Table 1. The commercial fertilizer source was ammonia nitrate and total amounts of $\mathrm{N}, \mathrm{P}$, and $\mathrm{K}$ applied are shown in Table 2. A 1.2 ET treatment was only conducted under mineral treatment (T1) in 


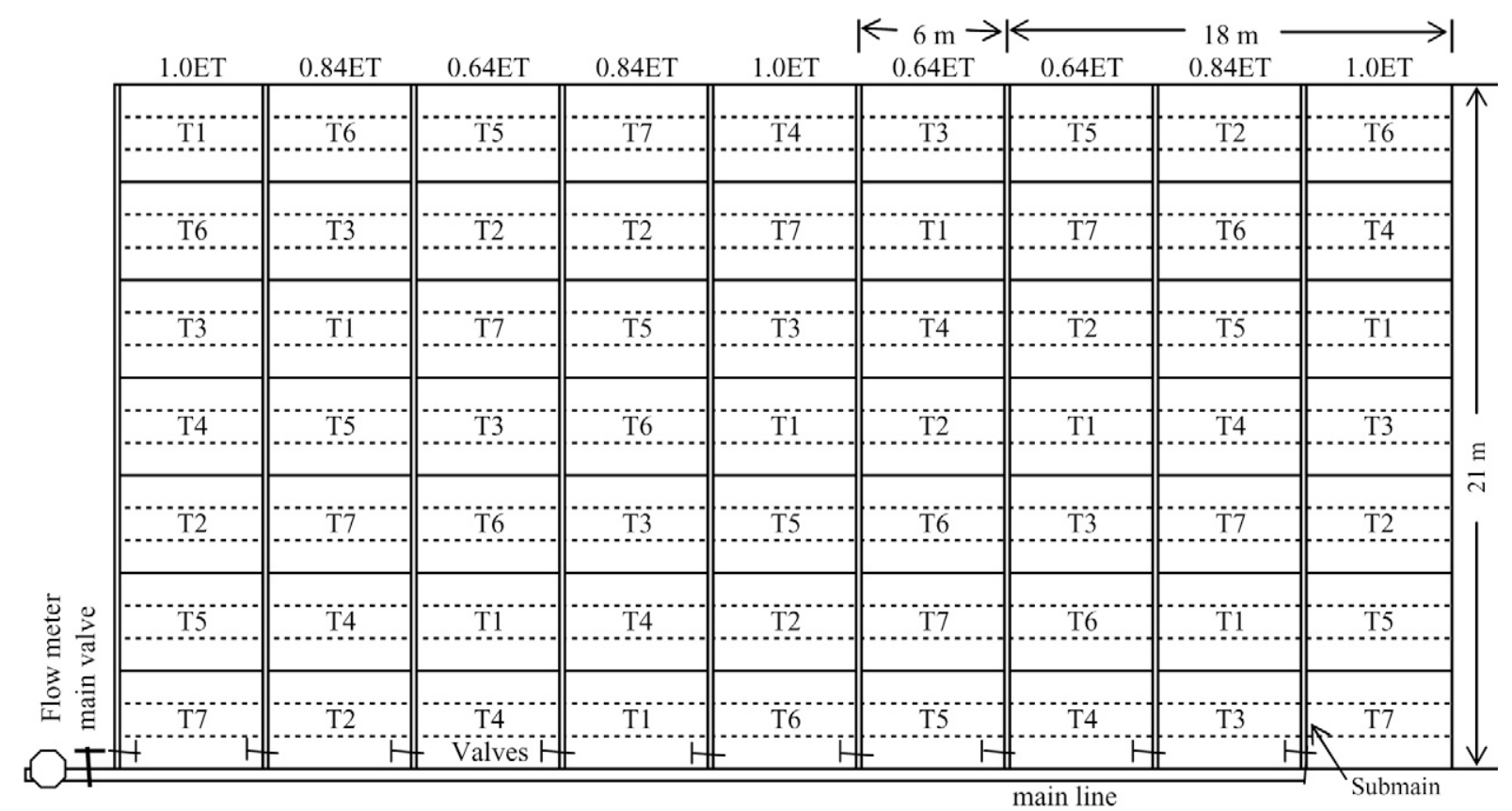

Fig. I. Experimental layout of the cucumber experiment in 2006 and 2007.

the experiment to determine cucumber yield under surplus irrigation. This treatment was replicated three times. The amount of nutrients added to the experimental field was the recommended rate for cucumber production in this area.

Soil was classified as loamy clay with $1.28 \mathrm{~g} / \mathrm{cm}^{3}$ soil bulk density. Soil particle sizes for $0.3 \mathrm{~m}$ of soil profile were distributed as $2 \%$ coarse sand, $23.5 \%$ fine sand, $37.7 \%$ silt, and $36.80 \%$ clay. Chemical analyses of the soil are shown in Table 3 . The volumetric water content values were measured using pressure membrane as $58,47.5$, and $21.1 \%$ at saturated, field capacity, and wilting points, respectively. The water table in the farm was recorded as $2.8 \mathrm{~m}$. Electrical conductivity (EC) and minerals were measured in diluted soil in three depths and sections of soil using a dilution ratio of $1: 5$.

The amount of irrigation, $d$, to be applied was determined in millimeters per irrigation interval based on the average of volumetric moisture content of soil root depth before and after irrigation as follows:

$$
\mathrm{d}=\left(\theta_{\mathrm{F}}-\theta_{\mathrm{i}}\right) \mathrm{D} \times \mathrm{P}
$$

Table I. Chemical properties of the manures used in the study.

\begin{tabular}{lcccccc}
\hline $\begin{array}{c}\text { Manure } \\
\text { fertilizer }\end{array}$ & $\begin{array}{c}\text { Total } \\
\text { organic } \\
\text { matter }\end{array}$ & pH & EC & N & P & K \\
\hline & $\%$ & & $d S / m$ & & $\%$ & \\
Farmyard & 39.20 & 6.20 & 3.40 & 0.50 & 0.51 & 0.60 \\
Rabbit & 41.40 & 6.18 & 3.30 & 1.70 & 1.18 & 1.05 \\
Chicken & 44.40 & 6.15 & 3.28 & 2.20 & 1.20 & 0.72 \\
\hline
\end{tabular}

where $\mathrm{d}$ is water applied depth in $\mathrm{mm}, \theta_{\mathrm{F}}$ is volumetric water content at field capacity $\mathrm{m}^{3} / \mathrm{m}^{3}, \theta_{i}$ is volumetric water content before irrigation in $\mathrm{m}^{3} / \mathrm{m}^{3}$, D is wetted soil root depth, and $\mathrm{P}$ is wetted area percentage. Ten soil samples from control treatment (1.0 ET with mineral treatment) were taken along the lateral before and after irrigation to the $60-\mathrm{cm}$ depth. The $0.3-\mathrm{m}$ spacing between $4 \mathrm{~L} / \mathrm{h}$ emitters combined to create a $0.41-\mathrm{m}$ wetted strip along planting line for the $32 \mathrm{~mm} / \mathrm{h}$ soil infiltration rate. Three soil samples from control treatment (1.0 ET with mineral treatment) were taken from each replicate along the lateral before and after irrigation to determine the averages of soil water content $\left(\theta_{\mathrm{F}}\right.$ and $\left.\theta_{\mathrm{i}}\right)$. The cucumber root zone was refilled by water until soil reached field capacity. The water table was greater than $2.8 \mathrm{~m}$. Only samples from $1.0 \mathrm{ET}$ were used to determine irrigation scheduling and water use ratios for $0.84 \mathrm{ET}$ and $0.64 \mathrm{ET}$. Deficit irrigation with no rainfall and ground water contributions can be considered as crop ET in a deficit situation per irrigation interval. At the experimental site there was no rainfall or ground water contribution during the study period.

Table 2. Total fertilizer rates the treatments for $\mathbf{N}, \mathbf{P}$, and $\mathrm{K}$.

\begin{tabular}{lrrrrrrr}
\hline Fertilizer & TI & T2 & T3 & T4 & T5 & T6 & T7 \\
\cline { 2 - 8 } N & & & & $\mathrm{kg} / \mathrm{ha}$ & & & \\
$\mathrm{P}$ & 160.0 & 165.0 & 245.0 & 199.0 & 279.0 & 234.0 & 314.0 \\
$\mathrm{~K}$ & 48.4 & 135.1 & 135.1 & 131.0 & 131.0 & 132.4 & 132.4 \\
\hline
\end{tabular}

Table 3. Soil chemical properties for the experimental site used in this study.

\begin{tabular}{|c|c|c|c|c|c|c|c|c|c|c|}
\hline \multirow[b]{3}{*}{ Depth } & \multirow[b]{3}{*}{$\mathrm{pH}$} & \multirow[b]{3}{*}{ EC } & \multicolumn{8}{|c|}{ Soluble ions } \\
\hline & & & \multicolumn{4}{|c|}{ Cations } & \multicolumn{4}{|c|}{ Anions } \\
\hline & & & $\mathrm{Ca}^{2+}$ & $\mathrm{Mg}^{2+}$ & $\mathrm{Na}^{+}$ & $\mathrm{K}^{+}$ & $\mathrm{CO}_{3}{ }^{2-}$ & $\mathrm{HCO}_{3}^{-}$ & $\mathrm{Cl}^{-}$ & $\mathrm{SO}_{4}{ }^{2-}$ \\
\hline $\mathrm{cm}$ & & $\mathrm{dS} / \mathrm{m}$ & & & & & & & & \\
\hline $0-30$ & 7.73 & 0.51 & 6.52 & 4.48 & 9.86 & 0.64 & 0.00 & 6.53 & 9.98 & 4.99 \\
\hline $30-60$ & 7.85 & 0.42 & 5.38 & 6.27 & 6.27 & 0.38 & 0.00 & 4.10 & 8.06 & 6.14 \\
\hline $60-90$ & 7.92 & 0.45 & 5.76 & 7.81 & 4.61 & 0.13 & 0.00 & 3.10 & 7.93 & 7.28 \\
\hline
\end{tabular}


Water applied for each irrigation (1.0 ET), was determined as follows:

$$
Q=\frac{\mathrm{dA}}{\mathrm{T}}
$$

where $Q$ is system discharge $\mathrm{L} / \mathrm{h}, \mathrm{d}$ is water depth in $\mathrm{mm}, \mathrm{A}$ is projected area in $\mathrm{m}^{2}$, and $T$ is irrigation time in $\mathrm{h}$.

The average depth of water distribution $Z_{\mathrm{a}}$ by system was determined as follows:

$$
Z_{\mathrm{a}}=\frac{\mathrm{T}}{\mathrm{A} \times \mathrm{P}} \sum_{i=1}^{n} q_{i}
$$

where $q_{i}$ is emitter discharge in the system $(\mathrm{L} / \mathrm{h})$ and $n$ is number of emitters in the projected area.

The scheduling parameter $(\alpha)$ was determined based on irrigation system as follows:

$$
\alpha=\frac{1}{\mathrm{CV}}\left(\frac{q}{q_{\mathrm{a}}}-1\right)
$$

where CV is the system's coefficient of variation, $q$ is scheduling of the emitter discharge, and $q_{\mathrm{a}}$ is average of the emitter discharge.

Meteorological instruments were positioned $2 \mathrm{~m}$ above the cucumber canopy and collected data every $30 \mathrm{~s}$ into $24 \mathrm{~h}$ average using Campbell Scientific's CR-23X ${ }^{1}$ datalogger (Campbell Scientific Inc., Logan, UT). Weather instruments were CS500 temperature and relative humidity probes, $03001-5$ anemometer, and LI200X pyranometer. The datalogger was programmed to collect daily and monthly average of weather data (temperature, relative humidity, wind speed, and solar radiation. These data were used to determine potential evapotranspiration $\left(\mathrm{ET}_{\mathrm{p}}\right)$ by two methods (Table 4): the FAO Penman-Monteith formula (Allen et al., 1998) and Class A pan evaporation $\left(\mathrm{E}_{\mathrm{p}}\right)$. Both $\mathrm{ET}_{\mathrm{p}}$ and $E_{\mathrm{p}}$ were correlated using the average of monthly weather data and formulated as follows:

$$
\mathrm{ET}_{\mathrm{p}}=k_{\mathrm{p}} \times \mathrm{E}_{\mathrm{p}}, \quad \text { with } r^{2}=0.91
$$

where $k_{\mathrm{p}}$ is a pan coefficient and recorded as 0.77 in the area. Crop coefficient was calculated only for treatment (T1) as the ratio of potential ET to measured ET.
Seventy-five days after transplanting in 2006 growing seasons, five plants were sampled from each experimental unit to determine chlorophyll $a$ and $b$ contents using the methods of Wettstein (1957) in 2006 and 2007 growing seasons. The same leaf samples were used to determine the leaf area/plant and leaf area index (LAI) from the method described by Watson (1958). Male and female flowers were counted during the intensive flowering period from 30 June to 15 July 2006 and 2007 seasons to estimate sex ratio (male/female flowers). Fruit harvesting was performed during the period from 4 June to15 August in both seasons. The statistical analysis of experimental data was performed using the Statistical Analysis System (SAS Institute, 2003). Measured data were analyzed by ANOVA. Duncan's method was statistically used to find out the differences among means. Significance evaluation was hypothesized based on 5\% significant level ( $p \leq 0.05)$.

Crop response between yield and water use under deficit irrigation was determined by a linear response model (Doorenbos and Kassam, 1979; Martin et al., 1984; Warrick and Gardner, 1983; Solomon, 1983; Sammis and Wu, 1985; Wu and Barragan, 2000). The linear model showed a sloped straight line in the deficit water application and a horizontal line for the crop response for surplus applications indicating no yield reduction by overirrigation. The crop response to deficit irrigation was expressed when water was uniformly applied as follows:

$$
1-\frac{\mathrm{Y}}{\mathrm{Y}_{\mathrm{m}}}=K_{\mathrm{y}}\left(1-\frac{\mathrm{W}}{\mathrm{W}_{\mathrm{m}}}\right)
$$

where $\mathrm{Y}_{\mathrm{m}}$ and $\mathrm{W}_{\mathrm{m}}$ represent maximum yield and its corresponding maximum water application, $\mathrm{Y}$ and $\mathrm{W}$ are yield and its corresponding water application under deficit conditions, and $K_{\mathrm{y}}$ is a reduction coefficient which is considered as a constant for a crop in deficit irrigation.

In practicality, irrigation systems apply water with a degree of nonuniformity. If irrigation amount applied $(d)$ is considered between minimum and maximum depths of water distribution $\left(Z_{\min } \leq d \leq Z_{\max }\right)$, then the area wetted by irrigation system will be divided into surplus and deficit areas. Then, the situation will be called underirrigation conditions. When $d \geq$ $Z_{\max }$, the whole area will be deficit irrigated. For $d \leq Z_{\min }$, the whole area will be surplus irrigated.

Table 4. Meteorological data at Shibin El-Kom, Egypt during the 2006 and 2007 growing seasons. $\dagger$

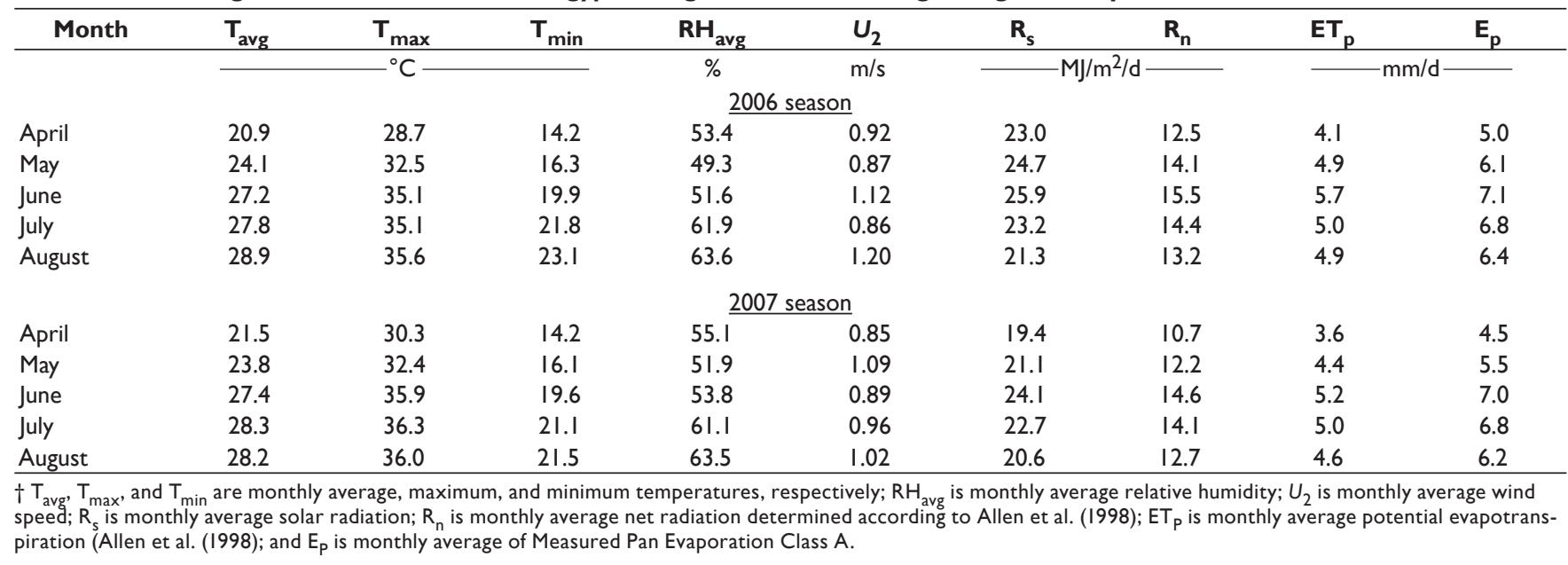


In underirrigation conditions, the crop yield will be varied in the deficit areas and maximized in adequate and surplus areas. Wu (1988) and Wu and Barragan (2000) formulated the relative crop yield under trickle irrigation systems as follows:

$$
1-\frac{\mathrm{Y}}{\mathrm{Y}_{\mathrm{m}}}=K_{\mathrm{y}} \mathrm{P}_{\mathrm{D}}
$$

where $\mathrm{P}_{\mathrm{D}}$ is the deficit percentage expressed as whole number.

In underirrigation conditions, the deficit percentage is defined as the ratio of water deficit to the required water into the root zone and can be formulated using linear distribution for water applied by the irrigation system according to Amer (2005) as follows:

$$
P_{D}=\frac{(1.725+\alpha)^{2} C V}{6.9(1+\alpha C V)}
$$

The schedule parameter $(\alpha)$ specifies the deviation of any schedule irrigation depth $(d)$ to average of water distribution depth $\left(Z_{\mathrm{a}}\right)$ in terms of $\mathrm{CV}$ and can be formulated as follows:

$$
\alpha=\frac{1}{\mathrm{CV}}\left(\frac{\mathrm{d}}{Z_{\mathrm{a}}}-1\right)
$$

where $d$ is the water depth expressing the plant water requirement and $Z_{\mathrm{a}}$ is average water distribution depth applied by irrigation system. When the linear distribution is used to express the water profile of the irrigation system, $\alpha$ will range from -1.725 to 1.725 in underirrigation conditions, $\alpha \geq 1.725$ in deficit irrigation, and $\alpha \leq-1.725$ in surplus irrigation.

The total relative yield in the underirrigation conditions $\left(Z_{\min } \leq d \leq Z_{\max }\right.$ and $\left.-1.725 \leq \alpha \leq 1.725\right)$ is affected by the system's coefficient of variation (CV) and schedule parameter $(\alpha)$ and can be calculated by substituting the left side of Eq. [7] by $P_{\mathrm{D}}$ in Eq. [6] as follows:

$$
\frac{\mathrm{Y}}{\mathrm{Y}_{\mathrm{m}}}=1-K_{\mathrm{y}} \frac{(1.725+\alpha)^{2} \mathrm{CV}}{6.9(1+\alpha \mathrm{CV})}
$$

Table 5. Means and standard deviations of chlorophyll $a$ and $b$ values in the 2006 growing season.

\begin{tabular}{lcc}
\hline & \multicolumn{2}{c}{ Mean \pm SE } \\
\cline { 2 - 3 } Treatments & Chlorophyll $\boldsymbol{a}$ & Chlorophyll $b$ \\
\hline Irrigation & $0.349 \pm 0.002 \mathrm{C} \dagger$ & $0.097 \pm 0.002 \mathrm{C}$ \\
$0.64 \mathrm{ET}$ & $0.800 \pm 0.002 \mathrm{~B}$ & $0.151 \pm 0.002 \mathrm{~B}$ \\
$0.84 \mathrm{ET}$ & $1.097 \pm 0.002 \mathrm{~A}$ & $0.200 \pm 0.002 \mathrm{~A}$ \\
I.0 ET & & $0.730 \pm 0.003 \mathrm{G}$ \\
Fertilizer & $0.640 \pm 0.003 \mathrm{~F}$ & $0.093 \pm 0.003 \mathrm{~F}$ \\
TI & $0.630 \pm 0.003 \mathrm{G}$ & $0.083 \pm 0.003 \mathrm{G}$ \\
T2 & $0.650 \pm 0.003 \mathrm{E}$ & $0.110 \pm 0.003 \mathrm{E}$ \\
T3 & $0.690 \pm 0.003 \mathrm{D}$ & $0.163 \pm 0.003 \mathrm{D}$ \\
T4 & $0.800 \pm 0.003 \mathrm{C}$ & $0.187 \pm 0.003 \mathrm{C}$ \\
T5 & $0.840 \pm 0.003 \mathrm{~B}$ & $0.200 \pm 0.003 \mathrm{~B}$ \\
T6 & $0.950 \pm 0.003 \mathrm{~A}$ & $0.210 \pm 0.003 \mathrm{~A}$ \\
T7 &
\end{tabular}

In complete deficit conditions, when $\alpha \geq 1.725$ and $d \geq Z_{\max }$, no deep seepage has occurred. The deficit percentage can be described as follows:

$$
\mathrm{P}_{\mathrm{D}}=\frac{\alpha \mathrm{CV}}{1+\alpha \mathrm{CV}}=1-\frac{Z_{\mathrm{a}}}{\mathrm{d}}
$$

Relative yield by the deficit conditions can then be determined as follows:

$$
\frac{Y}{Y_{\mathrm{m}}}=1-K_{\mathrm{y}} \frac{\alpha \mathrm{CV}}{1+\alpha \mathrm{CV}}
$$

or

$$
\frac{\mathrm{Y}}{\mathrm{Y}_{\mathrm{m}}}=1-K_{\mathrm{y}}\left(1-\frac{Z_{\mathrm{a}}}{\mathrm{d}}\right)
$$

When a relationship is drawn between relative yield $\mathrm{Y} / \mathrm{Y}_{\mathrm{m}}$ and schedule parameter $(\alpha)$ using Eq. [9] and [11], it will be affected by system's coefficient of variation. In the relationship between relative yield and relative scheduling irrigation depth $\left(Z_{\mathrm{a}} / \mathrm{d}\right)$ as shown in Eq. [12], the coefficient of variation will be insignificant when $\alpha$ is larger than 1.725. In the case of $\mathrm{CV}=0$, the relative irrigation depth will be unity for optimal scheduling and $\mathrm{d}$ will equal $Z_{\mathrm{a}}$.

The storage efficiency $\left(\mathrm{E}_{\mathrm{s}}\right)$ was determined as:

$$
\mathrm{E}_{\mathrm{s}}=100\left(1-P_{d}\right)
$$

In complete surplus irrigation conditions $(\alpha \leq-1.725$ and $\left.d \leq Z_{\text {min }}\right)$, the whole area will be surplus irrigated. In complete surplus irrigation conditions, storage efficiency will be $100 \%$ because the root zone is fully irrigated $\left(P_{\mathrm{D}}=0\right)$. But application efficiency, $\mathrm{E}_{\mathrm{a}}$, will have a value less than $100 \%$ depending on uniformity CV. Application efficiency can then be determined using the following equation:

$$
\mathrm{E}_{\mathrm{a}}=100\left(1-\mathrm{P}_{\mathrm{s}}\right)
$$

where $\mathrm{P}_{s}$ is the percentage of deep seepage in unity.

The percentage of deep seepage can be described using a linear distribution as derivative in this work following the basic analyses by Amer (2005) as follows:

In underirrigation,

$$
\mathrm{P}_{\mathrm{s}}=\frac{(1.725-\alpha)^{2} \mathrm{CV}}{6.9}
$$

In surplus irrigation,

$$
\mathrm{P}_{\mathrm{s}}=-\alpha \mathrm{CV}=1-\frac{\mathrm{d}}{Z_{\mathrm{a}}}
$$

\section{RESULTS AND DISCUSSION Chlorophyll}

Chlorophyll $a$ and $b$ values obtained during the 2006 season are shown in Table 5 . The $F$ value in Table 6 showed highly significant differences within either irrigation or fertilizer treatments. It showed no significant interaction between ET and fertilizer treatments. Both chlorophyll $a$ and $b$ were 
Table 6. Mean square, $F$ value, and probability for chlorophyll $a$ and $b$ in 2006 season.

\begin{tabular}{|c|c|c|c|c|}
\hline \multirow[b]{2}{*}{ Items } & \multicolumn{2}{|c|}{ Mean square } & \multicolumn{2}{|c|}{$F$ value and probability } \\
\hline & $\begin{array}{c}\text { Chlorophyll } \\
a\end{array}$ & $\begin{array}{c}\text { hlorophyll } \\
b\end{array}$ & $\begin{array}{c}\text { Chlorophyll } \\
a\end{array}$ & $\begin{array}{c}\text { Chlorophyll } \\
b\end{array}$ \\
\hline ET & $5.9670857 \mid$ & 0.1112 & 29835.43* & $556^{*}$ \\
\hline Fertilizer & $0.78737 \mid 43$ & 0.151886 & $1312.286 *$ & $253.14 *$ \\
\hline ET $\times$ fertilizer & $0.0005 I 429$ & 0.0012 & $0.42857 \mid 43$ & I nst \\
\hline Exp. error & 0.0042 & 0.0042 & & \\
\hline
\end{tabular}

significantly decreased with increasing water deficit. The highest chlorophyll values were achieved when adequate water was applied (1.0 ET) within a fertilizer treatment. Chlorophyll $a$ and $b$ significantly increased when $\mathrm{N}$ amounts increased (Table 5). The high chlorophyll values were obtained when chicken manure was used in combination with the recommended $\mathrm{N}$ and half-N doses ( $\mathrm{T} 7$ and $\mathrm{T} 6$ ). These treatments were followed by rabbit manure (T5 and T4) in combination with both mineral N. These results were explained by the chicken and rabbit manures containing more organic $\mathrm{N}$, which was available later in the growing season. Nitrogen was reported by Mardanov (1985) on squash and Mitchell et al. (1991) on lettuce (Lactuca sativa L.) to increase chlorophyll content. In the treatments with a half rate of $\mathrm{N}$ in combination with the chicken or rabbit manure there was a significant difference in chlorophyll $a$. A significant difference was found in chlorophyll $a$ among rabbit manure, farmyard manure, and mineral treatments. Chlorophyll $b$ differences were significant among all treatments. Higher chlorophyll $a$ and $b$ produced higher fruit yields. The cucumber fruit yield ( $\mathrm{Y}$ in $\mathrm{Mg} / \mathrm{ha}$ ) related to chlorophyll $a$ and $b(\mathrm{mg} / 100 \mathrm{~g}$ fresh wt.) within irrigation treatments in 2006 growing season were linearly correlated as follows:

Chlorophyll $a$ was found to be in the range of 0.23 to

$1.3 \mathrm{mg} / 100 \mathrm{~g}$ fresh wt.

$100 \%$ irrigation $\mathrm{Y}=40.70 a-9.235$ with $\mathrm{r}^{2}=0.90$.

$84 \%$ irrigation $Y=41.31 a+2.379$ with $r^{2}=0.92$.

$64 \%$ irrigation $\mathrm{Y}=36.07 a+18.15$ with $r^{2}=0.93$.

Chlorophyll $b$ was in the range of 0.03 to 0.26

$\mathrm{mg} / 100 \mathrm{~g}$ fresh wt.

$100 \%$ irrigation $\mathrm{Y}=92.11 b+17$ with $\mathrm{r}^{2}=0.95$.

$84 \%$ irrigation $\mathrm{Y}=78.79 b+23.07$ with $r^{2}=0.95$.

$64 \%$ irrigation $Y=106.2 b+19.34$ with $r^{2}=0.98$.
Table 7. Means and standard error for cucumber yield, sex ratio, and leaf area index (LAI).

\begin{tabular}{cccc}
\hline & \multicolumn{3}{c}{ Mean \pm SE } \\
\cline { 2 - 4 } Items & Yield & Sex ratio & LAl \\
\hline Year & & & \\
2006 & $30.655 \pm 0.03 I B^{*}$ & $3.459 \pm 0.006 \mathrm{~B}$ & $8.567 \pm 0.013 \mathrm{~B}$ \\
2007 & $30.789 \pm 0.03 \mathrm{~A}$ & $4.619 \pm 0.006 \mathrm{~A}$ & $8.881 \pm 0.013 \mathrm{~A}$ \\
Irrigation & & & \\
$0.64 \mathrm{ET}$ & $25.954 \pm 0.039 \mathrm{C}$ & $3.202 \pm 0.008 \mathrm{C}$ & $7.926 \pm 0.015 \mathrm{C}$ \\
$0.84 \mathrm{ET}$ & $30.651 \pm 0.039 \mathrm{~B}$ & $4.706 \pm 0.008 \mathrm{~A}$ & $8.844 \pm 0.015 \mathrm{~B}$ \\
I.0 ET & $35.560 \pm 0.039 \mathrm{~A}$ & $4.209 \pm 0.008 \mathrm{~B}$ & $9.403 \pm 0.015 \mathrm{~A}$ \\
Fertilizer & & & \\
T1 & $26.197 \pm 0.059 \mathrm{~F}$ & $3.577 \pm 0.012 \mathrm{G}$ & $8.220 \pm 0.024 \mathrm{E}$ \\
T2 & $25.550 \pm 0.059 \mathrm{G}$ & $3.583 \pm 0.012 \mathrm{~F}$ & $7.990 \pm 0.024 \mathrm{~F}$ \\
T3 & $27.598 \pm 0.059 \mathrm{E}$ & $3.903 \pm 0.012 \mathrm{E}$ & $8.265 \pm 0.024 \mathrm{E}$ \\
T4 & $31.318 \pm 0.059 \mathrm{D}$ & $4.283 \pm 0.012 \mathrm{~B}$ & $8.725 \pm 0.024 \mathrm{D}$ \\
T5 & $31.882 \pm 0.059 \mathrm{C}$ & $4.638 \pm 0.012 \mathrm{~A}$ & $9.050 \pm 0.024 \mathrm{C}$ \\
T6 & $36.095 \pm 0.059 \mathrm{~B}$ & $4.083 \pm 0.012 \mathrm{D}$ & $9.200 \pm 0.024 \mathrm{~B}$ \\
T7 & $36.413 \pm 0.059 \mathrm{~A}$ & $4.203 \pm 0.012 \mathrm{C}$ & $9.620 \pm 0.024 \mathrm{~A}$ \\
\hline * Treatment means with the different letter are significant at the $p \leq 0.05$ level.
\end{tabular}

\section{Leaf Area Index}

Leaf area index (LAI) differences were significant between the two growing seasons even though there was less solar radiation in 2007 compared to 2006 (Tables 7 and 8). Leaf area index, measured at full growth, showed significant differences among irrigation treatments at the $5 \%$ level for the same fertilizer treatment. Leaf area index showed significant differences among fertilizer treatments (Table 7) but not between $\mathrm{T} 1$ against $\mathrm{T} 2$. The results in Table 8 showed no interactions among year, fertilizer, and irrigation treatments. Leaf area index was significantly different among all irrigation treatments within a fertilizer treatment. The highest LAIs were obtained when water was adequately applied (1.0 ET treatment). These results are in agreement with those of Saleh and Ibrahim (2007) working on cantaloupe (Cucumis melo L.). There were significant differences at the $5 \%$ level for mineral and farmyard manure treatments (T1, T2, and T3) with less vegetative growth than the chicken manure with both $\mathrm{N}$ rates (T6 and T7) within an irrigation treatment. The half rate of $\mathrm{N}$ combined with farmyard manure (T2) had the lowest LAI values in both years (Table 7). The recommended rate of $\mathrm{N}$ combined with chicken manure had the largest LAI in both years (Table 7). Differences in LAI were significant among rabbit and chicken treatments for all irrigation levels. The highest LAI was found in both growing seasons in the T7 and 1.0 ET treatment. These results could be explained by organic fertilizers, especially chicken and rabbit manures, having contributed

Table 8. Mean square, $F$ value, and probability for cucumber yield, sex ratio, and leaf area index (LAI) in 2006 and 2007 seasons.

\begin{tabular}{|c|c|c|c|c|c|c|}
\hline \multirow[b]{2}{*}{ Items } & \multicolumn{3}{|c|}{ Mean square } & \multicolumn{3}{|c|}{$F$ value and probability } \\
\hline & Yield & Sex ratio & LAI & Yield & Sex ratio & LAI \\
\hline Year & 0.56 & 42.42 & 3.1 & $8.96 *$ & $16968.48^{*}$ & $311.14 *$ \\
\hline ET & 968.99 & 24.65 & 23.34 & $15503.82 *$ & $9858.2^{*}$ & $2333.7 *$ \\
\hline Fertilizer & 359.84 & 2.663 & 6.42 & $5757.4^{*}$ & $1065.2^{*}$ & $641.74 *$ \\
\hline Year $\times$ ET & 0.681 & 3.571 & 0.0051 & $|0.89|^{*}$ & $1428.2 *$ & $0.508 \mathrm{nst}$ \\
\hline Year $\times$ fertilizer & 0.621 & $0.0006 \mathrm{I}$ & 0.0021 & $9.9328^{*}$ & $0.2428 \mathrm{~ns}$ & $0.208 \mathrm{~ns}$ \\
\hline ET $\times$ fertilizer & 4.715 & 0.00074 & 0.0145 & $75.44 *$ & $0.294 \mathrm{~ns}$ & $1.45 \mathrm{~ns}$ \\
\hline Year $\times$ ET $\times$ fertilizer & 0.32 & 0.00074 & 0.0028 & $5.14 I^{*}$ & $0.2944 \mathrm{~ns}$ & $0.275 \mathrm{~ns}$ \\
\hline Exp. error & 0.0625 & 0.0025 & 0.01 & & & \\
\hline
\end{tabular}

* Significant at the $p \leq 0.05$ level.

$\dagger \mathrm{ns}=$ nonsignificant 


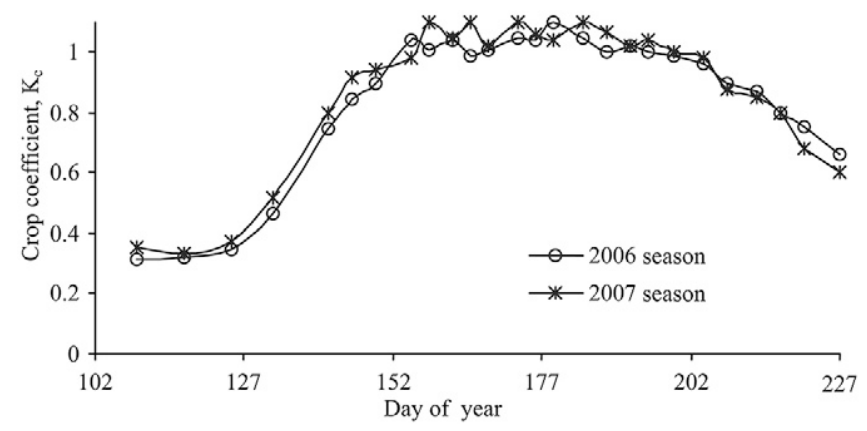

Fig. 2. Cucumber crop coefficient during both the 2006 and 2007 growing seasons.

to cucumber vegetative growth by causing the soil to store water and by adding large amounts of $\mathrm{N}$.

\section{Sex Ratio}

Significant differences in sex ratios (male/female flowers) occurred with increasing irrigation water deficit (Tables 7 and 8). The $F$ value in Table 7 showed significant differences among treatments in irrigation, fertilizer, or year with no interaction among them. The highest values of sex ratio were achieved when $64 \%$ of adequate water was applied $(0.64 \mathrm{ET})$ within a fertilizer treatment. Water deficit increased sex ratio as it increases carbohydrate accumulation according to Randhawa and Singh (1972), who found lower carbohydrates and higher $\mathrm{N}$ contents in cantaloupe plants resulted in the induction of female flowers. The relation between carbohydrates and sex ratio was previously observed in squash by Mardanov (1985). Cucumber sex ratio significantly decreased when $\mathrm{N}$ application increased within an irrigation treatment. The lowest values were obtained for a recommended rate of $\mathrm{N}$ supplemented with chicken manure (T7) followed by half $\mathrm{N}$ rate plus chicken manure (T6), followed by rabbit manure in combination with $\mathrm{N}$ rates within irrigation treatments (Table 7). Decreasing sex ratio meant an increase in female flowers and this appeared logical as $\mathrm{N}$ was frequently reported to positively affect female flowers in cucumbers. These results are in agreement with those of Abd El-Fattah and Sorial (2000) on squash and El-Dakish (2004) on cucumber. A significant difference occurred between mineral treatments (T1) compared with chicken and rabbit manure treatments (T4, $\mathrm{T} 5, \mathrm{~T} 6$, and T7). There were significant differences among T5, $\mathrm{T} 6$, and T7. Decreasing sex ratio leads to a greater potential fruit yield because of the increase in the number of female flowers per plant, which develop into fruit compared with male flowers, which provide the pollen for fertilization. Average fruit yield in both growing seasons increased linearly as sex ratio decreased in a range of 3.7 to 4.9 as in the following equation:

$$
\mathrm{Y}(\mathrm{Mg} / \mathrm{ha})=-10.09 X+74.16 r^{2}=0.882
$$

where $X$ is sex ratio.

\section{Crop Coefficient}

The cucumber crop coefficient $\left(\mathrm{K}_{\mathrm{C}}\right)$ under trickle irrigation was determined as the ratio of actual $\left(\mathrm{ET}_{\mathrm{c}}\right)$ to potential $\left(\mathrm{ET}_{\mathrm{p}}\right)$ evapotranspiration for 1.0 ET treatment with mineral fertilization (T1) as illustrated in Fig. 2 in both seasons. The average length of both growing seasons was $125 \mathrm{~d}$. The seasonal amount of actual water

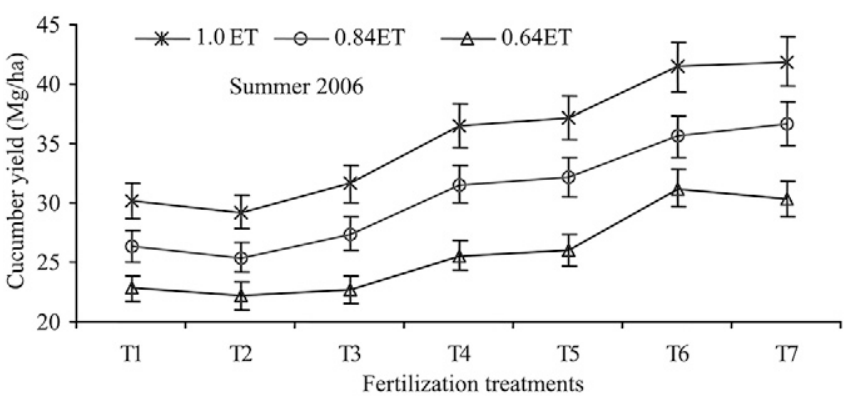

Fig. 3. Cucumber yield vs. fertilization treatments at $5 \%$ level in 2006.

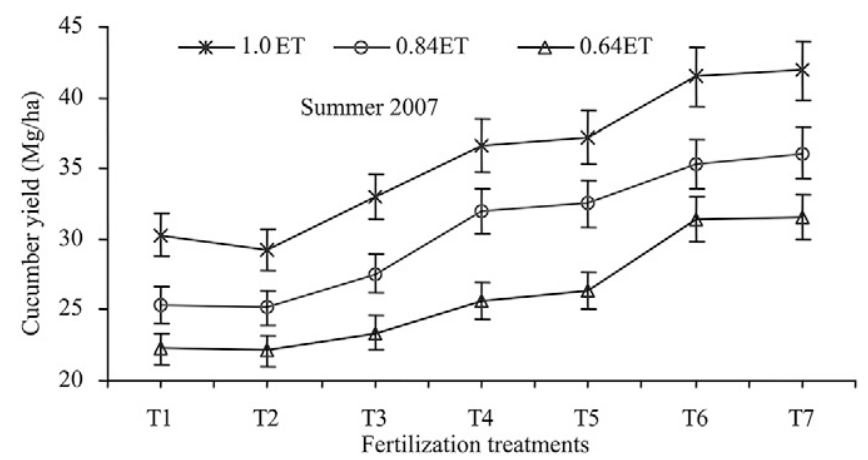

Fig. 4. Cucumber yield vs. fertilization treatments at $5 \%$ level in 2007.

use applied in 26 irrigation events was 498 in 2006 and $471 \mathrm{~mm}$ in 2007. The initial values of $K_{C}$ ranged from 0.32 to 0.37 for $22 \mathrm{~d}$ when cucumber ground cover ranged from 1.5 to $8 \%$, respectively, due to evaporation from the partially wetted soil area by trickle irrigation and a small amount of transpiration from the small leaf area. As the crop developed, $\mathrm{K}_{\mathrm{C}}$ showed a rapid increase from the early growth stages from almost 0.37 to 0.98 when ground cover reached $100 \%$ in $30 \mathrm{~d}$. At the full vegetative stage, $\mathrm{K}_{\mathrm{C}}$ fluctuated between 0.98 to 1.15 for $50 \mathrm{~d}$. The cucumber crop coefficient was insignificantly higher in 2007 season even though vegetative growth was larger compared to the 2006 season. The cucumber crop coefficient decreased during the senescence phase in less than $23 \mathrm{~d}$ from a value of 0.98 to almost 0.65 at the end of the 2006 season and 0.6 at the end of 2007 , because of senescing leaves.

\section{Crop Response}

Cucumber yield was affected by fertilizer form within an irrigation regime in both growing seasons (Fig. 3 and 4). Maximum cucumber yields $\left(\mathrm{Y}_{\mathrm{m}}\right)$ averaged across seasons for the $1.0 \mathrm{ET}$ irrigation treatment were $30.26,29.25,32.30,36.57,37.16$, 41.47, and $41.90 \mathrm{Mg} /$ ha for T1, T2, T3, T4, T5, T6, and T7, respectively. Yield for the 1.2 ET with T1 treatment was $30.8 \mathrm{Mg} / \mathrm{ha}$ in 2006 and $31.04 \mathrm{Mg} / \mathrm{ha}$ in 2007. A nonsignificant difference was found between cucumber yield obtained by both 1.0 ET and 1.2 ET treatments with mineral treatment (T1). Cucumber yield significantly decreased in linear relationship with increasing water deficit within fertilizer treatment. However, it was not significantly changed by water applied above 1.0 ET. The bars in Fig. 3 and 4 and the standard deviations in Table 7 clarify the error range using $5 \%$ percentage level. The highest yields were achieved with the 1.0 ET treatment. Similar results were obtained by Mao et al. (2003) on cucumber and Saleh and Ibrahim (2007) on cantaloupe. The $F$ 
Table 9. Cucumber yield-water function coefficients ( $m$ and $c$ ) and deficit reduction coefficient $\left(K_{y}\right)$ in two growing seasons.

\begin{tabular}{|c|c|c|c|c|c|c|c|c|}
\hline \multirow[b]{2}{*}{ Coefficients $\dagger$} & \multicolumn{8}{|c|}{ Fertilization treatments } \\
\hline & TI & T2 & T3 & T4 & T5 & T6 & T7 & Avg. \\
\hline \multicolumn{9}{|c|}{2006 Growing season } \\
\hline$m$ & 0.050 & 0.047 & 0.061 & 0.075 & 0.076 & 0.069 & 0.079 & 0.0653 \\
\hline c & 9.368 & 9.538 & 6.713 & 6.011 & 6.15 & 12.94 & 9.73 & 8.636 \\
\hline$K_{y}$ & 0.72 & 0.7 & 0.8 & 0.85 & 0.844 & 0.726 & 0.78 & 0.774 \\
\hline$r^{2}$ & 0.99 & 0.986 & 0.99 & 0.99 & 0.97 & 0.974 & 0.96 & 0.978 \\
\hline \multicolumn{9}{|c|}{$\underline{2007 \text { Growing season }}$} \\
\hline$m$ & 0.043 & 0.039 & 0.052 & 0.06 & 0.06 & 0.054 & 0.057 & 0.0521 \\
\hline c & 7.726 & 9.19 & 6.113 & 6.174 & 7.003 & 13.33 & 12.89 & 8.92 \\
\hline$K_{y}$ & 0.75 & 0.71 & 0.86 & 0.83 & 0.82 & 0.727 & 0.73 & 0.775 \\
\hline$r^{2}$ & 0.962 & 0.977 & 0.97 & 0.99 & 0.986 & 0.961 & 0.98 & 0.975 \\
\hline
\end{tabular}

$\dagger K_{y}$, reduction coefficient; $m$ and $c$ are, respectively, slope and intercept in linear regression equation, $Y=m W+c$, where $Y$ is yield in $\mathrm{Mg} / \mathrm{ha}$ and $\mathrm{W}$ is water applied in $\mathrm{mm}$.

values in Table 8 showed a significant effect of manure source on cucumber yield with yields highly increased with rabbit or chicken manures (T4, T5, T6, and T7) compared with treatment (T1) within irrigation treatment. Yield was insignificant among T1, T2, and T3 (mineral and farmyard manure fertilizers treatments). The highest yields were achieved using chicken manure compared with the other fertilizer treatments. The minimum value of yield was achieved using half rate of $\mathrm{N}$ with farmyard manure (T2), which had less $\mathrm{N}$ and slower $\mathrm{N}$ release from organic manure than other treatments. Chicken manure was reported by Ahmed (2004) to increase bulb yield of onion. Rabbit and chicken manures were found by El-Dakish (2004) to positively affect female flowers and consequently fruit yield of cucumber and a similar result was observed in this study. Cucumber yield was significantly higher in the 2007 season since vegetative growth was significantly lower in the 2006 season. The fertilizer treatments (T6 and T7) showed an increase in yield across all irrigation treatments in both years (Table 7; also see Fig. 3 and 4). Results showed that year, irrigation, and fertilizer effects on cucumber yield were significant (Table 8) and interaction actually existed among them.

Cucumber yield-water function was a linear relationship within fertilizer treatment. Crop yield ( $\mathrm{Mg} / \mathrm{ha}$ ) increased by increasing irrigation water applied $(\mathrm{mm})$ in a range of 260 to $406 \mathrm{~mm}$ in 2006 and 321 to $502 \mathrm{~mm}$ in 2007. The cucumber production function is shown in Table 9. Yield reduction coefficient $\left(K_{\mathrm{y}}\right)$ derived from Eq. [5] from deficit irrigation within the fertilizer treatments is provided in Table 9. Crop response to water

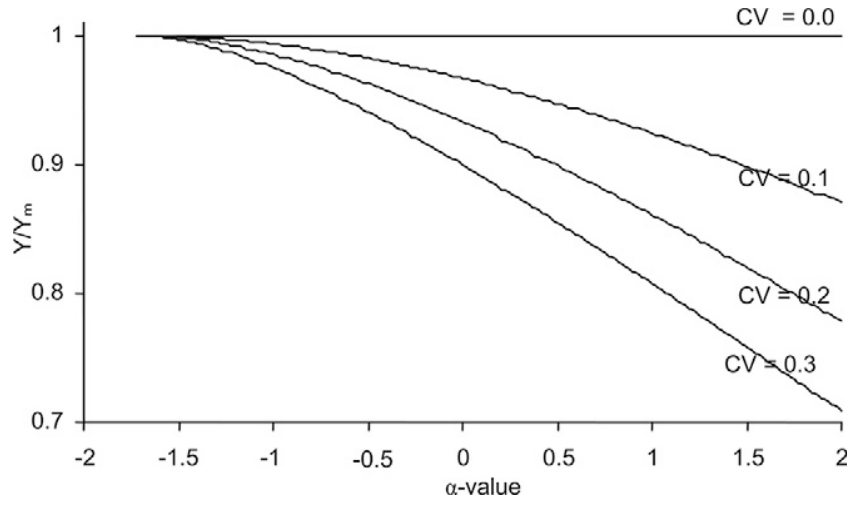

Fig. 5. Cucumber relative yield $\left(Y / Y_{m}\right)$ vs. irrigation schedule parameter $(\alpha)$. changed according to the amount of water applied; however, the yield response to $\mathrm{N}$ showed inconsistencies due to varying $\mathrm{N}$ sources. The mean reduction coefficient was 0.77 with deficit irrigation.

\section{Optimal Irrigation Scheduling}

Relative cucumber yield was related to irrigation schedule parameter, $\alpha$, for different uniformity CV values as shown in Fig. 5. Relative yield $\mathrm{Y} / \mathrm{Y}_{\mathrm{m}}$ in the underirrigation situation (Eq. [9]) was determined when $\alpha$ values were between \pm 1.725 . In complete deficit $(\alpha \geq 1.725)$,

Eq. [9] reduced to Eq. [11] showing the relationship between relative yield and $\alpha$ beyond underirrigation conditions. Based on a study by Amer (2001) in Egypt when irrigation system CVs were less than 30\%, complete overirrigation was desired because water cost was insignificant compared with return yield. Consequently, optimal scheduling was derived from the maximization of yield. Figure 5 shows the optimal scheduling parameter $\alpha$ was reported as -1.725 for any system's $C V$. These results show that overirrigation $(\alpha \leq-1.725)$ did not reduce the yield by testing 1.2 ET in this study and based on Doorenbos and Kassam (1979) and Sammis and $\mathrm{Wu}(1986)$ for vegetables. Maximum yield was achieved for all CV values as the water applied was adequate. Therefore, relative optimum scheduling depth that achieved maximum yield could be expressed as: $(1-1.725 \mathrm{CV})$. On the contrary, relative yield was reduced when water applied was insufficient. It was evident that the yield was significantly affected by both $\alpha$ and $\mathrm{CV}$ in underirrigation and complete deficit situations.

The relationship between cucumber relative yield $\left(\mathrm{Y} / \mathrm{Y}_{\mathrm{m}}\right)$ and relative depth $\left(d / Z_{\mathrm{a}}=1+\alpha \mathrm{CV}\right)$ for different uniformity $\mathrm{CV}$ values is shown in Fig. 6. The curves started at the end of the overirrigation stage when storage efficiency was $100 \%$ and when $\alpha$ was -1.725 . Optimum relative irrigation depths $\left(d / Z_{\mathrm{a}}\right)$ that achieved maximum yield were $1.0,0.828,0.655$, and 0.483 for $C V$ values of $0.0,0.1,0.2$, and 0.3 , respectively. The resultant application efficiency was found to be $100,82.8,65.5$, and $48.3 \%$, respectively. The curves diverged in underirrigation situations and demonstrate that yield was significantly affected by both $d / Z_{\mathrm{a}}$ and $\mathrm{CV}$. Hence,

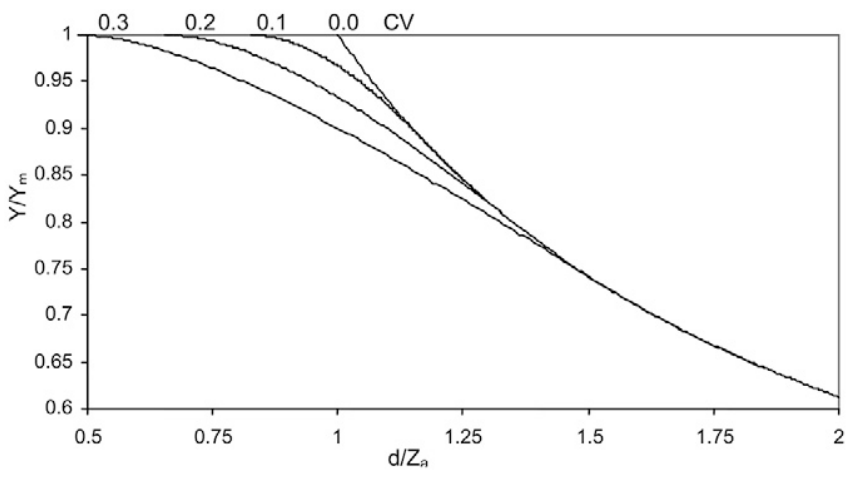

Fig. 6. Cucumber relative yield $\left(\mathrm{Y} / \mathrm{Y}_{\mathrm{m}}\right)$ vs. relative irrigation depth $\left(d / Z_{a}\right)$. 
application efficiency increased and storage efficiency decreased by increasing water deficit. Relative irrigation depth values at the start of complete deficit (when application efficiency achieved 100\%) were recorded as 1.0, 1.173, 1.345, and 1.518, and for the CV values as $0.0,0.1,0.2$, and 0.3 , respectively. Consequently, storage efficiency was calculated to be $100,85.3,74.3$, and $65.9 \%$, respectively. These curves coincided in complete deficit irrigation, meaning that the uniformity was an insignificant parameter when too little water was applied. In the case of $\mathrm{CV}=0.3$, the significance of uniformity was only in a range of $d / Z_{a}$, between 0.48 and 1.52 , and beyond that range was insignificant. Optimum irrigation scheduling depth under different irrigation system uniformities could be taken as a ratio from adequate water treatment (1.0 ET). Water cost was of insignificant importance compared with return yield, and when yield was affected only by deficit irrigation, the ratios $\left(Z_{\mathrm{a}} / d\right)$ could be determined by either dividing 1.0 ET by $(1-1.725 \mathrm{CV})$ or $100 \%$ ET by application efficiency and resulted in 1.0, 1.21, 1.53, 2.07 ET at system's uniformity CV as $0.0,0.1,0.2$, and 0.3 , respectively. Consequently, the whole area was completely overirrigated when schedule depth $(d)$ equalled minimum applied depth $\left(Z_{\min }\right)$. These conclusions are in agreement with those of Wu and Gitlin (1983) and Wu and Barragan (2000) using mathematical models.

\section{CONCLUSION}

Cucumber grown in optimal weather and soil conditions requires both water and nutrient availability. Irrigation systems are essential to apply water in arid regions; however, optimal use of water to meet crop requirements is essential to achieve maximum water use efficiency. Organic fertilizers offer the potential to recover nutrients from animal operations but are not used as frequently with the availability of commercial fertilizers. Growers are becoming interested in using animal manures as substitutes for commercial fertilizers and there is little information about the combinations of commercial fertilizer and manures under different irrigation management regimes. This study focused on cucumber growth and yield as affected by both water and $\mathrm{N}$ management. Maximum cucumber yield was obtained with adequate water applied within fertilizer treatment and with increasing amounts of $\mathrm{N}$ applied. Leaf chlorophyll $a$ and $b$ and LAI were greatest when irrigation amounts were maintained as $1.0 \mathrm{ET}$ and when high rates of $\mathrm{N}(314 \mathrm{~kg} / \mathrm{ha})$ were applied with a combination of commercial fertilizers and manures. The ratio of male/female flowers, which is the primary factor reducing cucumber yield, increased with decreasing amounts of $\mathrm{N}$ and water. Cucumber yield was not increased by surplus irrigation treatment. Results showed that year, irrigation, and fertilizer could individually or together significantly improve the cucumber yield. Management of cucumber for maximum yield requires optimizing irrigation water supply in combination with $\mathrm{N}$ management.

\section{REFERENCES}

Abd El-Fattah, M.A., and M.E. Sorial. 2000. Sex expression and productivity responses of summer squash to bio fertilizer application under different nitrogen levels. Egyptian J. Agric. Res. 2(27):98-107.

Ahmed, M.E. 2004. A study on the effect of organic materials and chemical fertilization on growth, yield and chemical composition of onion (Allium cepa L.). Egyptian J. Agric. Res. 29(5):1147-1159.

Ahmet, E., S. Sensoy, C. Kucukyumuk, and I. Gedik. 2004. Irrigation frequency and amount affect yield components of summer squash (Cucurbita pepo L.). Agric. Water Manage. 67:63-76.
Allen, R.G., L.S. Pereira, D. Raes, and M. Smith. 1998. Crop evapotranspiration: Guidelines for computing crop water requirements. Irrigation and Drainage Paper 56. FAO, Rome.

Al-Omran, A.M., A.S. Shetaa, A.M. Falataha, and A.R. Al-Harbi. 2005. Effect of drip irrigation on squash (Cucurbita pepo) yield and water-use efficiency in sandy calcareous soils amended with clay deposits. Agric. Water Manage. 73:43-55.

Amer, K.H. 2001. Comparison between modern irrigation system designs. Ph.D. thesis. Minufiya University, Egypt.

Amer, K.H. 2005. Trickle irrigation evaluation and schedules. Egyptian J. Agric. Eng., Egypt 22(3):899-922.

Doorenbos, J., and A.H. Kassam. 1979. Yield response to water. Irrigation Drainage Paper 33. FAO, Rome.

El-Dakish, M.H. 2004. Growth development and yield of cucumber as affected by irrigation frequency and mineral fertilization versus organic manure. Assiut Univ. Bull. Environ. Res. 7(2):65-76.

Enciso, J., J. Morales, B. Wiedenfeld, S. Nelson, and X. Peries. 2007. Irrigating onions with subsurface drip irrigation under different stress levels. p. 338-352. In Proc. 28th International Irrigation Conf., San Diego, CA. 9-11 Dec. 2007. Irrigation Association, San Diego, CA.

Hanson, B., D. May, R. Voss, M. Cantwell, and R. Rice. 2003. Response of garlic to irrigation water. Agric. Water Manage. 58:29-43.

Li, J., and X. Wang. 2000. The present studying situation and existing problems of water-saving irrigation index for vegetable. (In Chinese.) Agric. Res. Arid Areas 18:118-123.

Mao, X., M. Liu, X. Wang, C. Liu, Z. Hou, and J. Shi. 2003. Effects of deficit irrigation on yield and water use of greenhouse grown cucumber in the North China Plain. Agric. Water Manage. 61:219-228.

Mardanov, A.A. 1985. Effect of cytokines on shoot and root growth of nitrogen deficient plants. Fiziologija Rastenii (Russian J. Plant Physiol.) 32(6):1120-1126. C.F. Hort. Abst. 56(8):6232.

Martin, D.L., D.G. Watts, and J.R. Gilley. 1984. Model and production function for irrigation management. J. Irrig. Drain. Div. 110(2):149-164.

Mitchell, C.A., H. Leokokos, and T.L. Ford. 1991. Modification of yield and chlorophyll content in leaf lettuce by HPS radiation and nitrogen treatments. HortScience 26(11):1371-1374.

Randhawa, K.S., and K. Singh. 1972. Total soluble nitrogen and carbohydrate contents of floral buds of muskmelon (Cucumis melo L.) and their influence in sex modification. Indian J. Agric. Univ. Ludhiana. C.F. Hort. Abst. 43(12):8663.

Saleh, M.M., and M.A. Ibrahim. 2007. Effect of different irrigation levels on production, quality, and storage ability of cantaloupe (Cucumis melo L.) grown under polyethylene low tunnels in a newly reclaimed land. Egyptian J. Agric. Res. 32(4):1109-1124.

Sammis, T.W., and I.P. Wu. 1985. Effect of drip irrigation design and management on crop yield. Trans. ASAE 28(3):832-838.

Sammis, T.W., and I.P. Wu. 1986. Fresh market tomato yields as affected by deficit irrigation using a micro-irrigation system. Agric. Water Manage. 12:117-126.

SAS Institute. 2003. User's guide. SAS Inst., Cary, NC.

Simseka, M., T. Tonkaz, M. Kacıra, N. Comlekcioglu, and K. Dogan. 2005. The effects of different irrigation regimes on cucumber (Cucumbis sativus $\mathrm{L}$.) yield and yield characteristics under open field conditions. Agric. Water Manage. 73:173-191.

Solomon, K. 1983. Irrigation uniformity and yield theory. Ph.D. thesis. Utah State Univ., Logan.

Warrick, A.W., and W.R. Gardner. 1983. Crop yield as affected by spatial variations of soil and irrigation. Water Res. 19(1):181-186.

Watson, D.J. 1958. The dependence of net assimilation rate on leaf area index. Ann. Bot. N.S. 22:37-54.

Wettstein, D. 1957. Chlorophyll, letal under submikro svopische formmech cellder-plastiden. Exp. Cell Res. 12:427-433.

Wu, I.P., and H.M. Gitlin. 1983. Drip irrigation application efficiency and schedules. Trans. ASAE 26(1):92-99.

Wu, I.P. 1988. Linearized water application function for drip irrigation schedules. Trans. ASAE 31(6):1743-1749.

Wu, I.P., and J. Barragan. 2000. Design criteria for microirrigation systems. Trans. ASAE 43(5):1145-1154.

Yuan, B.Z., J. Sun, Y. Yaohu Kang, and S. Nishiyama. 2006. Response of cucumber to drip irrigation water under a rainshelter. Agric. Water Manage. 81:145-158. 